\title{
Application of National Sanitation Foundation and Weighted Arithmetic Water Quality Indices for the Assessment of Kaani and Kpean Rivers in Nigeria
}

\author{
Kalagbor I.A., ${ }^{1 *}$, Johnny V. I. ${ }^{2}$, Ogbolokot I. E. ${ }^{2}$ \\ ${ }^{1}$ Research \& Development Centre, Kenule Beeson Saro-Wiwa Polytechnic P.M.B. 20 Bori Rivers State \\ ${ }^{2}$ Department of Science Laboratory Technology, School of Applied Sciences, \\ Kenule Beeson Saro-Wiwa Polytechnic P.M.B. 20 Bori Rivers State \\ *Corresponding author: ksinachi@yahoo.com
}

Received December 14, 2018; Revised January 15, 2019; Accepted January 27, 2019

\begin{abstract}
Rivers present a continuous renewable physical resource for domestic and agricultural purposes. Kaani and Kpean rivers in Bori town in Rivers state, Nigeria are the common sources of water to the people. The water quality assessment of these rivers is carried out using fifteen physicochemical parameters. These parameters were measured for three consecutive months of July, August and September 2017 at three sampling points for each river. These months are the months of the rainy season. The samples were analysed using the standardized method of the American Public Health Association (APHA). The concentrations of all the analysed parameters were compared to World Health Organization (WHO) guidelines for drinking water. National Sanitation Foundation Water Quality Index (NSF WQI) and Weighted Arithmetic Water Quality Index (WA WQI) were used for assessment. The NSF WQI values of 59.77 and 63.45 were obtained for Kaani and Kpean respectively. The NSF WQI was able to give a good evaluation of the gradual change in the water quality of these two rivers as they flowed through the communities from Kaani to Kpean. The results obtained using the WA WQI gave values of 1.68 and 6.04 for Kaani and Kpean respectively indicating that these water bodies have excellent water quality rating and both methods find useful application in the assessment of Kaani and Kpean and rivers. This study shows that in the months of the rainy season, these two rivers have good water quality and are fit for use.
\end{abstract}

Keywords: assessment, communities, Kaani, Kpean, Water quality rating, WQI

Cite This Article: Kalagbor I.A., Johnny V. I., and Ogbolokot I. E., "Application of National Sanitation Foundation and Weighted Arithmetic Water Quality Indices for the Assessment of Kaani and Kpean Rivers in Nigeria." American Journal of Water Resources, vol. 7, no. 1 (2019): 11-15. doi: 10.12691/ajwr-7-1-2.

\section{Introduction}

Rivers are the most important freshwater resources for man. Apart from its function as a source of freshwater for drinking, domestic and industrial uses; freshwater resources serve multiple functions most of them being critical to human settlement and survival. Adequate supply of safe and sanitized freshwater is an inevitable factor for human and economic development [1]. Report by [2] revealed that in African countries, water related diseases had been interfering with basic human development. The common sources of water that are available to local communities in Nigeria are fast being severed by a number of anthropogenic factors of which pollution remain the most dominant problem. This is because dead vegetation, metal leachates from solid waste dump, leaching of rocks, sewage, industrial wastes and agricultural chemicals return eventually to the river by runoffs [3]. Water abstraction for domestic use, agricultural production, mining, industrial production, power generation and forestry practical can lead to deterioration in water quality and quantity that impacts not only the aquatic ecosystem but also the availability of safe water for human consumption [4]. Rivers have been used as a sink for wastes from agriculture and industry due to its flow and ecological nature. Rivers are able to regenerate themselves to admit staggering amount of tributaries. However, all rivers have limited absorptive capacity for sewage and fertilizer from cropland or farmland. Pollution of surface water occurs when too much of an undesirable or harmful substance flows into a body of water, exceeding the natural ability of that water body [5]. Water quality monitoring indexing is one of the ways by which the quality of a water system could be assessed [6]. It is important to regularly monitor the water body since this action helps to reveal how healthy and hygienic the water is for domestic use, industrial and agricultural purposes [7]. The quality of water is the most important factor affecting lives in the ecosystem. Rivers and lakes being important fresh water sources are often polluted by natural and anthropogenic sources thereby making them unfit for use. Several authors have carried out studies on the physicochemical and microbial properties of some rivers 
in Nigeria [8-13]. Other studies reveal high concentrations of heavy metals in our rivers, the effect of municipal solid waste discharge and the impact of brewery, tannery and industrial waste water [14-19] on the physiochemical properties of these rivers. However, these studies report the assessment of rivers and lakes based on the physiochemical, microbial and heavy metals content only. The aim of this study is to analyze fourteen physicochemical parameters and the microbial parameter of Kaani and Kpean rivers using standard methods. The results obtained will be applied to National Sanitation Foundation (NSF) and Weighted Arithmetic (WA) water quality indices (WQI) to determine the water quality rating of these rivers.

\section{Materials and Method}

\subsection{Study Area}

These two rivers flow through so many communities in Ogoniland in Rivers State. Waters from Gokana and Yeghe empties into the Kaani River. The Kpean River has tributaries from Kono and Opobo. Both rivers met at a confluence point and then flow into the Imo River which then empties into the Bight of Bonny. These rivers are primarily used for fishing, swimming and as potable water. Majority of the people close to the river continue to depend on these rivers for their domestic and agricultural needs. The Figure 1 below is a map showing the two rivers and the sampling sites.

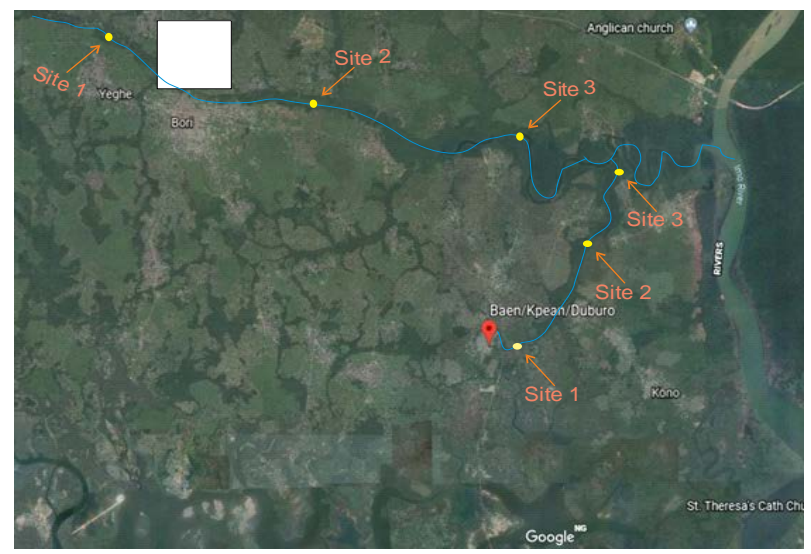

Figure 1. Map showing the two rivers and their sampling points

\subsection{Water Sample Collection}

Water samples were taken from both rivers (Kaani and Kpean) at three different sampling sites as marked in Figure 1 (Site1, Site 2 and Site 3) which correspond to upstream, midstream and downstream respectively in each of the rivers. The water samples were collected in duplicates in sterilized $150 \mathrm{ml}$ plastic bottles and sealed with tight stopper and cap to avoid air bubbles. These were taken to the laboratory for analyses.

\subsection{Methods}

\subsubsection{Physicochemical Analysis}

Temperature and $\mathrm{pH}$ were measured in-situ using a Hanna instrument (HI 9813-6). Total solids (TS) and total dissolved solids (TDS) were determined by gravimetric methods as described by [20]. Dissolved oxygen (DO) was determined using oxygen analyzer (model JPB - 607). The conductivity measurements were carried out using a conductivity meter (Hanna conductivity meter model EC 215) and the turbidity was measured using a turbidity meter (Xinrui WGZ - IB Shanghai). The other physicochemical parameters were later analyzed in the laboratory using the stipulated methods in [20]. These include; biological oxygen demand (BOD), chemical oxygen demand (COD), the anions $\left(\mathrm{Cl}^{-}, \mathrm{NO}_{3}^{-}\right.$and $\mathrm{PO}_{4}^{2-}$ ), the cations $\left(\mathrm{Mg}^{2+}\right.$ and $\left.\mathrm{Ca}^{2+}\right)$ and fecal coliform. The chemicals and reagents used in these analyses were of analytical grade from $\mathrm{BDH}$.

\subsubsection{NSFWQI Calculations}

This method was developed by [21] to provide a standardized method for comparing the water quality of various bodies of water using nine water quality parameters. These are $\mathrm{pH}$, temperature, turbidity, fecal coliform, dissolved oxygen (DO), biochemical oxygen demand (BOD), total phosphates, nitrate and total solids according to [22]. Results obtained for each parameter are compared to the weighting chart curve and a numerical value $(\mathrm{Q}$ - value) is obtained and used in the mathematical expression below for NSF WQI:

$$
W Q I=\sum_{i=1}^{n} Q i W i
$$

Where Qi = sub-index for ith water quality parameter; $\mathrm{Wi}=$ weight associated with ith water quality parameter; $\mathrm{n}=$ number of water quality parameters.

For this NSFWQI method, the ratings of water quality have been defined by using the following Table 1 :

Table 1. Water Quality Rating for National Sanitation Foundation Water Quality Index (NSFWQI)

\begin{tabular}{|l|l|}
\hline WQI Value & Ratings of Water Quality \\
\hline $91-100$ & Excellent water quality \\
\hline $71-90$ & Good water quality \\
\hline $51-70$ & Medium water quality \\
\hline $26-50$ & Bad water quality \\
\hline $0-25$ & Very bad water quality \\
\hline
\end{tabular}

Source: Shweta et al., 2013.

\subsubsection{Weighted Arithmetic WQI, Method and Calculations}

This method has been widely used by various scientists [23,24,25] using the most commonly measured water quality variables [26]. The calculation involves the use of the following mathematical equation:

$$
W Q I=\frac{\sum Q_{n} W_{n}}{\sum W_{n}}
$$

Where $Q_{n}$ is the quality rating scale for each parameter for the nth water quality parameter

$\mathrm{W}_{\mathrm{n}}$ is the unit weight for each water quality parameter

$$
Q_{n}=100\left[\frac{V_{n}-V_{o}}{S_{n}-V_{o}}\right]
$$


Where $V_{n}$ is observed value (ie estimated concentration of nth parameter in the analyzed water

$\mathrm{V}_{\mathrm{o}}$ is the ideal value of this parameter in pure water $\left(\mathrm{V}_{\mathrm{o}}=0(\right.$ except $\mathrm{pH}=7.0$ and $\left.\mathrm{DO}=14.6 \mathrm{mg} / \mathrm{L})\right)$

$\mathrm{S}_{\mathrm{n}}$ is the recommended standard value of nth parameter by WHO.

$$
W_{n}=\frac{K}{S_{n}}
$$

where $\mathrm{K}=1$.

The rating of water quality according to this WQI is given in Table 2.

Table 2. Water Quality Rating as per Weight Arithmetic Water Quality Index Method

\begin{tabular}{|c|c|c|}
\hline WQI Value & Rating of Water Quality & Grading \\
\hline $0-25$ & Excellent water quality & A \\
\hline $26-50$ & Good water quality & B \\
\hline $51-75$ & Poor water quality & C \\
\hline $76-100$ & Very poor water quality & D \\
\hline Above 100 & Unsuitable for drinking purpose & E \\
\hline
\end{tabular}

Source: Shweta e. al., 2013.

\section{Results and Discussion}

\subsection{Results}

Presented in Table 3 and Table 4 are the descriptive statistics of the results obtained from the analysis of the parameters in this study for Kpean river and Kaani river respectively while Table 5 to Table 8 are the results of the calculations for Water Quality Indices for Kpean and Kaani using NSF and WA methods.

Table 3. Descriptive Statistics for the Parameters in Kpean River

\begin{tabular}{|c|c|c|c|c|c|}
\hline & \multirow{2}{*}{ Parameters } & \multicolumn{3}{|c|}{ Average Values } & \multirow[b]{2}{*}{ Mean values } \\
\hline & & July & August & September & \\
\hline 1 & $\mathrm{pH}$ & 7.93 & 6.93 & 8.17 & 7.68 \\
\hline 2 & Temp $\left({ }^{0} \mathrm{C}\right)$ & 25.17 & 23.40 & 24.80 & 24.46 \\
\hline 3 & Turbidity (NTU) & 0.23 & 3.72 & 0.28 & 1.41 \\
\hline 4 & Conductivity $(\mu \mathrm{s} / \mathrm{cm})$ & 123.77 & 150.73 & 123.83 & 132.78 \\
\hline 5 & (DO mg/L & 11.57 & 18.57 & 36.20 & 22.11 \\
\hline 6 & BOD mg/L & 2.23 & 8.43 & 2.50 & 4.39 \\
\hline 7 & COD (mg/L) & 32.03 & 27.57 & 39.90 & 33.17 \\
\hline 8 & $\mathrm{NO}_{3}^{-}(\mathrm{mg} / \mathrm{L})$ & 19.60 & 21.30 & 26.07 & 22.32 \\
\hline 9 & $\mathrm{Cl}^{-}(\mathrm{mg} / \mathrm{L})$ & 29.13 & 32.53 & 43.13 & 34.93 \\
\hline 10 & $\mathrm{PO}_{4}{ }^{2-}(\mathrm{mg} / \mathrm{L})$ & 0.07 & 0.13 & 0.28 & 0.16 \\
\hline 11 & Total Solid (TS) mg/L & 0.33 & 0.37 & 0.40 & 0.37 \\
\hline 12 & TDS mg/L & 0.20 & 0.20 & 0.20 & 0.20 \\
\hline 13 & $\mathrm{Mg}^{2+}(\mathrm{mg} / \mathrm{L})$ & 26.93 & 25.20 & 30.17 & 27.42 \\
\hline 14 & $\mathrm{Ca}^{2+}(\mathrm{mg} / \mathrm{L})$ & 23.47 & 24.63 & 26.27 & 24.79 \\
\hline 15 & Fecal coliform & 9.67 & 58.67 & 78.67 & 49.0 \\
\hline
\end{tabular}

Table 4. Descriptive Statistics for the Parameters in Kaani River

\begin{tabular}{|c|l|c|c|c|c|}
\hline \multirow{2}{*}{ S/N. } & \multirow{2}{*}{ Parameters } & \multicolumn{3}{|c|}{ Average Values } & \multirow{2}{*}{ Mean values } \\
\cline { 2 - 5 } & & July & August & September & \\
\hline 1 & $\mathrm{pH}$ & 7.20 & 5.83 & 7.10 & 6.71 \\
\hline 2 & Temp ( $\left.{ }^{\circ} \mathrm{C}\right)$ & 26.87 & 27.03 & 27.23 & 27.04 \\
\hline 3 & Turbidity (NTU) & 0.31 & 3.96 & 0.44 & 1.57 \\
\hline 4 & $\mathrm{Conductivity}(\mu \mathrm{s} / \mathrm{cm})^{*}$ & 140.33 & 153.77 & 143.67 & 145.92 \\
\hline 5 & $\mathrm{DO}^{(\mathrm{mg} / \mathrm{L})}$ & 22.07 & 22.63 & 28.37 & 24.36 \\
\hline 6 & $\mathrm{BOD}^{(\mathrm{mg} / \mathrm{L}}$ & 5.13 & 11.87 & 6.57 & 7.86 \\
\hline 7 & $\mathrm{COD}^{(\mathrm{mg} / \mathrm{L})}$ & 10.83 & 13.13 & 12.17 & 12.04 \\
\hline 8 & $\mathrm{NO}_{3}{ }^{-}(\mathrm{mg} / \mathrm{L})$ & 11.17 & 20.93 & 16.87 & 16.32 \\
\hline 9 & $\mathrm{Cl}^{-}(\mathrm{mg} / \mathrm{L})$ & 32.53 & 43.03 & 33.13 & 36.23 \\
\hline 10 & $\mathrm{PO}_{4}{ }^{2-}(\mathrm{mg} / \mathrm{L})$ & 0.33 & 0.12 & 0.15 & 0.20 \\
\hline 11 & $\mathrm{TS}^{(\mathrm{mg} / \mathrm{L})}$ & 0.17 & 0.20 & 0.13 & 0.17 \\
\hline 12 & $\mathrm{TDS}^{(\mathrm{mg} / \mathrm{L})}$ & 0.13 & 0.20 & 0.13 & 0.16 \\
\hline 13 & $\mathrm{Mg}^{2+}(\mathrm{mg} / \mathrm{L})$ & 20.33 & 21.73 & 18.70 & 20.26 \\
\hline 14 & $\mathrm{Ca}^{2+}(\mathrm{mg} / \mathrm{L})$ & 22.53 & 32.83 & 27.07 & 27.48 \\
\hline 15 & Fecal coliform $^{2}$ & 10.33 & 24.67 & 49.33 & 28.11 \\
\hline
\end{tabular}

Table 5. Calculation of Water Quality Index for Kpean using the Weighted Arithmetic Method

\begin{tabular}{|c|c|c|c|c|c|}
\hline Parameters & $\begin{array}{c}\text { Observed } \\
\text { mean }\end{array}$ & WHO & $\begin{array}{c}\text { Unit } \\
\text { weight } \\
\text { (Wn) }\end{array}$ & $\begin{array}{c}\text { Quality } \\
\text { Rating } \\
\text { (qn) }\end{array}$ & Wnqn \\
\hline $\mathrm{pH}$ & 7.68 & 8.5 & 0.118 & 45.185 & 5.316 \\
\hline Temp $\left({ }^{0} \mathrm{C}\right)$ & 24.46 & 28 & 0.036 & 87.341 & 3.119 \\
\hline Turbidity (NTU) & 1.41 & 5 & 0.200 & 28.200 & 5.640 \\
\hline Conductivity $(\mu \mathrm{s} / \mathrm{cm})$ & 132.78 & 250 & 0.004 & 53.111 & 0.212 \\
\hline $\mathrm{DO} \mathrm{mg} / \mathrm{L}$ & 22.11 & 6 & 0.167 & -87.339 & -14.556 \\
\hline BOD mg/L & 4.39 & 10 & 0.100 & 43.889 & 4.389 \\
\hline COD (mg/L) & 33.17 & 150 & 0.007 & 22.111 & 0.147 \\
\hline $\mathrm{NO}_{3}{ }^{-}(\mathrm{mg} / \mathrm{L})$ & 22.32 & 50 & 0.020 & 44.644 & 0.893 \\
\hline $\mathrm{Cl}^{-}(\mathrm{mg} / \mathrm{L})$ & 34.93 & 250 & 0.004 & 13.973 & 0.056 \\
\hline $\mathrm{PO}_{4}{ }^{2-}(\mathrm{mg} / \mathrm{L})$ & 0.16 & 5 & 0.200 & 3.178 & 0.636 \\
\hline $\mathrm{TS} \mathrm{mg} / \mathrm{L}$ & 0.37 & 500 & 0.002 & 0.073 & 0.000 \\
\hline TDS mg/L & 0.20 & 500 & 0.002 & 0.040 & 0.000 \\
\hline $\mathrm{Mg}^{2+}(\mathrm{mg} / \mathrm{L})$ & 27.46 & 150 & 0.007 & 18.304 & 0.122 \\
\hline $\mathrm{Ca}^{2+}(\mathrm{mg} / \mathrm{L})$ & 24.79 & 200 & 0.005 & 12.394 & 0.062 \\
\hline
\end{tabular}

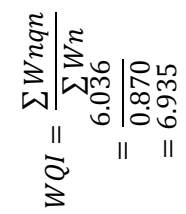


Table 6. Calculation of Water Quality Index for Kaani using the Weighted Arithmetic Method

\begin{tabular}{|c|c|c|c|c|c|}
\hline Parameters & $\begin{array}{l}\text { Observe } \\
\text { d mean }\end{array}$ & $\begin{array}{c}\text { WH } \\
\mathrm{O}\end{array}$ & $\begin{array}{c}\text { Unit } \\
\text { weight } \\
(\mathrm{Wn})\end{array}$ & $\begin{array}{c}\text { Quality } \\
\text { Rating } \\
\text { (qn) }\end{array}$ & Wnqn \\
\hline $\mathrm{pH}$ & 6.71 & 8.5 & 0.118 & -19.259 & -2.266 \\
\hline Temp $\left({ }^{\circ} \mathrm{C}\right)$ & 27.04 & 28 & 0.036 & 96.587 & 3.450 \\
\hline Turbidity (NTU) & 1.57 & 5 & 0.200 & 31.333 & 6.267 \\
\hline $\begin{array}{c}\text { Conductivity } \\
(\mu \mathrm{s} / \mathrm{cm})\end{array}$ & 145.92 & 250 & 0.004 & 58.369 & 0.233 \\
\hline DO (mg/L) & 24.36 & 6 & 0.167 & -113.49 & -18.95 \\
\hline BOD (mg/L) & 7.86 & 10 & 0.100 & 78.556 & 7.856 \\
\hline COD (mg/L) & 12.04 & 150 & 0.007 & 8.030 & 0.054 \\
\hline $\mathrm{NO}_{3}{ }^{-}(\mathrm{mg} / \mathrm{L})$ & 16.32 & 50 & 0.020 & 32.644 & 0.653 \\
\hline $\mathrm{CL}^{-}(\mathrm{mg} / \mathrm{L})$ & 36.23 & 250 & 0.004 & 14.493 & 0.058 \\
\hline $\mathrm{PO}_{4}{ }^{2-}(\mathrm{mg} / \mathrm{L})$ & 0.20 & 5 & 0.200 & 4.044 & 0.809 \\
\hline TS (mg/L) & 0.17 & 500 & 0.002 & 0.033 & 0.000 \\
\hline TDS (mg/L) & 0.16 & 500 & 0.002 & 0.031 & 0.000 \\
\hline $\mathrm{Mg}^{2+}(\mathrm{mg} / \mathrm{L})$ & 20.26 & 150 & 0.007 & 13.504 & 0.090 \\
\hline $\mathrm{Ca}^{2+}(\mathrm{mg} / \mathrm{L})$ & 27.48 & 200 & 0.005 & 13.739 & 0.069 \\
\hline $\begin{aligned} W Q I & =\frac{\sum W n q n}{\sum W n} \\
& =\frac{1.68}{0.870} \\
& =1.93\end{aligned}$ & & & $\sum_{=0.870} W n$ & & $\sum_{=1.68} W n q n$ \\
\hline
\end{tabular}

Table 7. Calculation of Water Quality Index using NSFWQI Method for Kpean

\begin{tabular}{|c|c|c|c|c|c|}
\hline Parameters & $\begin{array}{c}\text { Observed } \\
\text { mean }\end{array}$ & WHO & $\begin{array}{c}\text { Unit } \\
\text { weight } \\
(\mathrm{Wi})\end{array}$ & Q-values & WiQi \\
\hline $\mathrm{pH}$ & 7.68 & 8.5 & 0.118 & 90.000 & 10.588 \\
\hline Temp $\left({ }^{0} \mathrm{C}\right)$ & 24.46 & 28 & 0.036 & 16.500 & 0.589 \\
\hline Turbidity (NTU) & 1.41 & 5 & 0.200 & 90.500 & 18.100 \\
\hline $\mathrm{DO}(\mathrm{mg} / \mathrm{L})$ & 22.11 & 6 & 0.167 & 16.500 & 2.750 \\
\hline $\mathrm{BOD}(\mathrm{mg} / \mathrm{L})$ & 4.39 & 10 & 0.100 & 56.500 & 5.650 \\
\hline $\mathrm{PO}_{4}{ }^{2-}(\mathrm{mg} / \mathrm{L})$ & 0.16 & 5 & 0.200 & 96.000 & 19.200 \\
\hline $\mathrm{NO}_{3}{ }^{-}(\mathrm{mg} / \mathrm{L})$ & 22.32 & 50 & 0.020 & 30.500 & 0.610 \\
\hline $\mathrm{TS}_{(\mathrm{mg} / \mathrm{L})}$ & 0.37 & 500 & 0.002 & 80.000 & 0.160 \\
\hline Fecal Coliform & 49.00 & 10 & 0.100 & 58.000 & 5.800 \\
\hline
\end{tabular}

$W Q I=\sum_{i=1}^{n} Q_{i} W_{i}=63.448$.

Table 8. Calculation of Water Quality Index using NSFWQI Method for Kaani

\begin{tabular}{|c|c|c|c|c|c|}
\hline Parameters & $\begin{array}{c}\text { Observed } \\
\text { mean }\end{array}$ & WHO & $\begin{array}{c}\text { Unit } \\
\text { weight } \\
(\mathrm{Wi})\end{array}$ & Q-values & WiQi \\
\hline $\mathrm{pH}$ & 6.71 & 8.5 & 0.118 & 72.500 & 8.529 \\
\hline Temp $\left({ }^{0} \mathrm{C}\right)$ & 27.04 & 28 & 0.036 & 12.000 & 0.429 \\
\hline Turbidity (NTU) & 1.57 & 5 & 0.200 & 90.500 & 18.100 \\
\hline $\mathrm{DO}(\mathrm{mg} / \mathrm{L})$ & 24.36 & 6 & 0.167 & 16.500 & 2.750 \\
\hline $\mathrm{BOD}(\mathrm{mg} / \mathrm{L})$ & 7.86 & 10 & 0.100 & 42.000 & 4.200 \\
\hline $\mathrm{PO}_{4}{ }^{2-}(\mathrm{mg} / \mathrm{L})$ & 0.20 & 5 & 0.200 & 95.000 & 19.000 \\
\hline $\mathrm{NO}_{3}{ }^{-}(\mathrm{mg} / \mathrm{L})$ & 16.32 & 50 & 0.020 & 40.000 & 0.800 \\
\hline Total Solid (TS) mg/L & 0.17 & 500 & 0.002 & 80.000 & 0.160 \\
\hline Fecal Coliform & 28.11 & 10 & 0.100 & 58.000 & 5.800 \\
\hline
\end{tabular}

$W Q I=\sum_{i=1}^{n} Q_{i} W_{i}=\mathbf{5 9 . 7 6 8 . ~}$

\subsection{Discussion}

The average $\mathrm{pH}$ value for Kpean was 7.68 which are higher than that for Kaani (6.71). The maximum $\mathrm{pH}$ value obtained in this study for both rivers was 8.5 and this was in the month of July. These values however are within permissible limits of [27]. In August, the temperature of Kaani River was $28.3^{\circ} \mathrm{C}$ while temperatures in July and September were $27.3^{\circ} \mathrm{C}$ and $27.5^{\circ} \mathrm{C}$ respectively. For Kpean River, the maximum temperatures $\left(25.4^{\circ} \mathrm{C}\right.$ and $25.2^{\circ} \mathrm{C}$ ) were recorded only in July and September. Turbidity in both rivers was higher only in the month of August (4.20 NTU) and low (0.15 - 0.36 NTU) in the months of July and September. The average values for Kaani and Kpean were 1.57 NTU and 1.41 NTU respectively and these values were within WHO permissible limits. The conductivity values are high for both rivers. These values ranges from 130.7 - 160.0 s/cm for Kaani River while for Kpean River the values ranges from 120.4 - $150.9 \mu \mathrm{s} / \mathrm{cm}$ with maximum values occurring in the month of August for both rivers. DO values were higher in the month of September for both rivers; Kaani (28.37 mg/L) and Kpean (36.2 mg/L). The BOD values were very high in August in comparison with the values obtained in July and September for both rivers. COD values were found to be high at Site 3 sampling point for Kaani River and at Site 1 sampling point for Kpean River and these high values were recorded in the month of September. Temperature, BOD and conductivity values are higher in Kaani River while COD, TS and TDS were found to be higher in Kpean River. This could be attributed to the introduction of solid wastes at the downstream. The anions $\left(\mathrm{Cl}^{-}\right.$and $\left.\mathrm{PO}_{4}{ }^{2-}\right)$ are higher in Kaani, most probably due to the introduction of wastes and contaminants. The quantity of nitrates and fecal coliform decreased at Kaani River which is an indication of less eutrophication and fecal discharge. The levels of $\mathrm{Mg}^{2+}$ and $\mathrm{Ca}^{2+}$ in both rivers were constant $(20-27 \mathrm{mg} / \mathrm{L})$ throughout the period of study. Most of the parameters were higher in the month of August which is the peak of rainy season and is expected. This is in agreement with the findings of [1] and [28]. All the values obtained for the fourteen parameters used for Weighted Arithmetic WQI were within [27] permissible limits except the DO values (24.36 mg/L and $22.11 \mathrm{mg} / \mathrm{L}$ ) which were above the WHO permissible limits. The low WQI values for Kpean and Kaani rivers in Table 5 and Table 6 fell within Grade A rating (Excellent water quality) as shown in the Weighted Arithmetic weighting chart (Table 2) while the WQI values obtained for both rivers in Table 7 and Table 8 using NSF WQI method were 63.45 and 59.77 for Kpean and Kaani respectively. These values indicate that the two water bodies are of medium quality as shown in the NSF WQI chart (Table 1). The NSF WQI Method did not adequately represent the quality of both Kaani and Kpean rivers when compared to the WA WQI method. This inadequacy may be due to the fewer number of parameters (nine) used for the calculation. This was also observed by [22] in their study. The values from downstream (Site 3) samples were higher than those from the upstream (Site 1). This could be attributed to the level of anthropogenic activities in those rivers. This agrees with the results obtained by [28] and [29]. 


\section{Conclusion}

This study has provided a basis for expressing water quality by using just a single value leading to easier interpretation of the state of these rivers. The water quality indices obtained shows that in the months of July, August and September, these two rivers have good water quality and are fit for use. WA WQI incorporated fourteen out of the fifteen parameters analyzed as required by the method thereby giving a better assessment of the rivers when compared to NSF WQI method. However, the NSF WQI was able to give a good evaluation of the gradual change in the water quality of these two rivers as they flowed through the communities from Kaani to Kpean. The results obtained from these two measured methods are in agreement with the results of analysis of the individual parameters which were found to be within WHO permissible limits. It is recommended that water monitoring should be carried out more frequently and a data base generated in order to keep track of any seasonal changes and convey same to the communities who depend on these rivers for their source of livelihood.

\section{Acknowledgements}

The authors are grateful to the fishermen and canoe men who assisted us in this research by taking us to the six sampling points for water sample collection. We are also grateful to the indigenes who offered to show us the course for Kpean River which had so many tributaries.

\section{References}

[1] Ayobahan S.U., Ezenwa I.M., Orogun E.E., Uriri J.E. and Wemimo I.J, “Assessment of Anthropogenic Activities on Water Quality of Benin River”. Journal of Applied Sciences Environmental Management, 18(4), 629-636. 2014

[2] Food and Agricultural Organisation, "Coping with Water Scarcity", 2007 World Water Day, 22nd March, 2007. Available at http://www.fao.org/nr/water. 2007

[3] Ademola F.A, "Base Line Heavy Metals Concentration in river sediment within Okitipopo South east belt of the Nigeria bituminous sand field". Journal of chemical society of Nigeria, 33(2), 29-34. 2008.

[4] United Nations Environment Programme, "Water Quality for Ecosystem and Human Health". Published by the United Nations Environment Programme Global Environment Monitoring System (GEMS)/Water Programme, 132. 2006

[5] Agbabiake, T. O. and Oeyiola, G. P, "Microbial and physicochemical assessment of Foma River, Itanmo, Ilorin, Nigeria an important source of domestic water in Ilorin metropolis". Intl J. plant, animal and environment sciences, 2(1), 209-216. 2012.

[6] Goher, M.E., Hassan, A.M., Abdel-Moniem, I.A., Fahny, A.H. and El-Sayed, S.M. "Evaluation of Surface Water Quality and Heavy Metal Indices of Ismaila Canal, Nile River, Egypt”. Egyptian J. Aquatic Research, 40, 225-233. 2014.

[7] Poonam, T., Tanushree, B. and. Sukalyan, C. "Water Quality Indices -Important Tools for Water Quality Assessment: A Review”. Intl J. Adv Chem, 1, 15-28. 2013.

[8] Emoyan, O.O., Akporhonor, E.E. and Akpoborie, I.A. "Environmental Risk Assessment of River Ijana, Ekpan, Delta State Nigeria”, Chemical Speciation and Bioavailability, 20(1), 23-32. 2008.
[9] Chinedu, S.N., Obinna, C.N., Adetayo, Y.O. and Eze, V.N., "Assessment of Water Quality in Cannanland, Ota, Southwest Nigeria”, Agric. and Biol. J. North America. 2(4). 577-583. 2011.

[10] Cosmas A.A. and Samuel O.O. "Comparative Assessment of the Physico-chemical and Microbial Trends in Njaba River, Niger Delta Basin, South eastern Nigeria”. J. Water Resour and Protect, 3, 686-693. 2011.

[11] Salawu, K., Owolarafe, T.A., Barau, M.M., Lawal, T.A., Abubakar, M.A., Fadilu, M. and Nwachukwu, F.C. "Determination of Selected Heavy Metals in Seasonal River in Mariu Town, Zamfara State, Nigeria”. J. Environ and Earth Science, 4, 11-14. 2014.

[12] Nwoko, C.I.A., Ukiwe, L.N., Egereonu, U.U. and Ukachukwu, S.N. "Assessment of Seasonal Physico-chemical Parameters of Oguta Lake, Nigeria”. J. Adv in Chem, 11(7), 3759-3764. 2015.

[13] Kalagbor, I. A. and Tubonemi, T. A “Comparative Assessment of the Physicochemical, Microbial property and the levels of some Heavy Metals in Ekerekana Creek in Rivers State”. Intl J. App and Nat Sciences, 7(4), 9-18. 2018

[14] Ubalua, O.A. and Ezeronye, O.U. "Nutrients and Selected Physico-Chemical Analysis in the ABA Rivers Surface Waters Abia State, Nigeria”. Environment and Ecology, 23(1), 141-144. 2005.

[15] Igbinosa, E.O. and Oko, A.I. "Impact of Discharge Wastewater Effluents on the Physiscochemical Qualities of a Receiving Watershed in a Typical Rural Community”. Intl J. Environ Sci \& Technol, 6(2), 175-182. 2009.

[16] Alao, O., Arojojoye, O., Ogunlaja, O. and Famuyiwa, A. "Impact of Assessment of Brewery Effluent on Water Quality in Majawe, Ibadan, Southwestern Nigeria”, Researcher, 2(5), 21-28. 2010.

[17] Chinda, A. C., Braide, S. A. and Obunwo, C.C., "Water Quality of Streams receiving Municipal Waste Water in Port Harcourt Niger Delta, Nigeria”. Waste Water - Evaluation and Management. InTech, Croatia. 2011.

[18] Obunwo, C.C., Chinda, A.C. and Braide, S.A. "Assessment of the Physico-chemical Characteristics of Minichida Stream, Port-Harcourt, Nigeria”. J. Chem Soc Nigeria, 37, 132-136. 2012.

[19] Jaji, M.O., Bamgbose, O. Odukoya, O.O. and Arowolo, T.A, "Water Quality Assessment of Ogun River, Southwest Nigeria", Environ. Monitoring Assess. 133(3), 447-482. 2007.

[20] America Public Health Association (APHA) "Standard methods for the examination of water and waste water $20^{\text {th }}$ edition”. American Public Health Association, American Water Works Association and Water Environment Federation. Washington DC, USA. 1998.

[21] Brown, R. M., McClelland, N. I., Deininger, R.A. and Tozer, R.G. "Water quality index - do we dare"? Water Sewage Work, 117(10) 339-343. 1970

[22] Kumar, D. and Alappat, B. "NSF - Water Quality Index: Does it Represent the Experts’ Opinion?” Practice Periodical of Hazardous Toxic and Radioactive Waste Management, 13(1), 75-79. 2009.

[23] Chauhan, A. and Singh, S. "Evaluation of Ganga water for drinking purpose by water quality index at Rishikesh, Uttarakhand, India”. Report Opinion, 2(9), 53-61. 2010.

[24] Balan, I.N., Shivakumar, M. and Kumar, P.D.M., “An assessment of ground water quality using water quality index in Chennai, Tamil Nadu, India”. Chronicles Young Scientist, 3(2), 146-150. 2012

[25] Chowdhury, R.M., Muntasir, S.Y. and Hossain, M.M. "Water quality index of water bodies along Faridpur-Barisal road in Bangladesh”. Global Engineers \& Technologists Review, 2(3), 1-8. 2012.

[26] Shweta, T., Bhavtosh, S., Prashant, S. and Rajendra, D. "Water Quality Assessment in Terms of Water Quality Index”. American Journal of Water Resources. 1(3), 34-38. 2013.

[27] World Health Organization, "Guidelines for Drinking Water Quality”, $4^{\text {th }}$ Ed. NLM Classification, WA 675, World Health Organization, Geneva, Switzerland, 307-433. 2011.

[28] Nyodee, G. T. "Determination of Water Quality Index for Bangha Stream in Bangha Community, Rivers State, Nigeria”. Science and Industrial Technology Education Journal, 3(2), 182-189. 2016.

[29] Khawakara, M.A., Majid, S.N. and Hama, N.Y., "Determination of Water Quality Index (WQI) for Qalyasan Stream in Sulaimani City, Kuradistan Region of Iraq”, Intl J. Plant, Animal and Environ. Sc. 2(4), 148-157. 2012. 